\title{
Bone Mineral Density and Osteoporosis in Women of Rural and Urban Dwellers
}

\author{
Shamim M F Begum ${ }^{1}$, Rubina Begum ${ }^{2}$, Rajibul Alam ${ }^{3}$ \\ ${ }^{1}$ National Institute of Nuclear Medicine \& Allied Sciences, Dhaka \\ ${ }^{2}$ Institute of Nuclear Medicine and Allied Sciences, Dhaka \\ ${ }^{3}$ Dhaka Medical College Hospital, Dhaka
}

\begin{abstract}
Address for Correspondences: Prof. Dr. Shamim Momtaz Ferdousi Begum, Professor and Head Nuclear Nephrology, Division National Institute of Nuclear Medicine \& Allied Sciences, BAEC. Email: pragyna66@yahoo.com, telephone: +880-2-9665912, mobile +880-1711849903
\end{abstract}

\begin{abstract}
Introduction: Bone mineral density (BMD) is an important and measurable risk factor for osteoporotic fractures. Many studies showed higher bone mineral density and lower incidence of fracture in rural population compared to urban population. But all these studies were done in developed countries and very few studies were found in developing countries. This study was carried out to determine the bone mineral density (BMD) in women of both urban and rural dwellers and to evaluation the rate of occurrence of osteoporosis in these two groups.
\end{abstract}

Method: A total 376 women with age range 35 to 85 were analyzed and divided in two groups. Group I rural (n204) and group II urban (n- 172), who were studied at two different Nuclear Medicine centers of Dhaka with different problems specially for low back pain and joint pain. Bone mineral density of lumbar spines (L2-L4) in anterior-posterior position and hip were measured using the Dual Energy X-Ray Absorptiometry-DEXA (Norland XR36). The $T$ - scores were calculated and results were compared between rural and urban women. The history of physical activity, dietary intake of calcium, smoking habit, number of parity and socio-economic condition was also compared with BMD.

Results: The mean $\mathrm{T}$ score of lumber spines in rural group was $-2.31 \pm 1.10$ and in urban group was $-1.78 \pm 1.03$. The hip of rural group showed mean $T$ score $-3.11 \pm 1.09$ and urban group $-3.02 \pm 1.09$. Mean bone mineral density was lower in rural women than urban but statistically no significant difference was observed between the two groups $(\mathrm{P}<\mathbf{0 . 0 1}$ and $\mathrm{P}<\mathbf{0 . 0 2}$ respectively). In rural group $39.2 \%$ cases showed osteoporosis in lumbar spines and $76.4 \%$ cases in hip. In comparison the urban group revealed osteoporosis in lumbar spines in $22.7 \%$ cases and in hip $\mathbf{4 0 . 9 \%}$ cases.

Conclusion: This study revealed lower bone mineral density in rural women than urban in our study population but this difference is statistically not significant.
Key words: BMD, Urban, Rural, Osteoporosis

\section{INTRODUCTION}

Bone mineral density (BMD) is an important and measurable risk factor for osteoporotic fractures (1). There are many predisposing and safety factors in the development of osteoporosis (2). Menopauses, either natural, or surgical, and ageing are considered the most important risk factors of osteoporosis and osteopenia (3). The currently accepted definition of osteoporosis is "a systemic disease characterized by low bone mass and microarchitectural deterioration of bone tissue leading to enhanced bone fragility, and consequent increase in fracture risk"(4). The WHO study group definition of osteoporosis, osteopenia and health are intended to identify patients with high, intermediate and low risk of fracture respectively. The tests that forms the basis for he diagnosis of osteoporosis and prediction of fracture risk are bone mineral density (BMD) and bone mineral content (BMC) measurements. The "golden standard" for the assessment of bone mineral density and content is dual energy absorptiometry (5). Fractures related to osteoporosis are a major health problem in all developed countries. Many studies showed higher bone mineral density and lower incidence of fracture in rural population compared to urban population $(1,6)$. But all these studies were done in European and western countries and very few in developing countries. Bangladesh is a densely populated, low earning third world developing country. Sixty eighty percent people are living in rural areas with poverty and lack of knowledge. There is no exact 
data regarding the values of bone mineral density and the prevalence of osteoporosis among the women living in rural and urban environment in Bangladesh.

The aim of this study was to determine the bone mineral density in both urban and rural dwellers of Bangladeshi women and to evaluate the rate of occurrence of osteoporosis in these two groups.

\section{METHODS}

A total 376 women, age ranged 35 to 85 years residence of different districts of Bangladesh, including both rural and urban dwellers were studied. They were studied specially for low back pain and other health problems. The 376 women were divided in two groups. Group I rural (n-204, $54 \%$ ) and Group II urban (n- 172, $46 \%$ ). The person who lived in rural area before the age of 35 years was considered as rural dweller and who lived in urban area considered as urban dweller. Normally bone mass increases during the growth to reach peak between the ages of 25 to 35 years (7).

A medical history was taken from each person using a specially prepared questionnaire in order to evaluate previous chronic disease, age of menopause, number of parity, physical activity, and dietary intake of calcium, drugs, smoking habit and socio-economic condition of the women. The exclusion criteria were history of chronic illness affecting bone tissue and drug intake, which could affect bone mass like Anabolic Steroid, Bisphosphonates, Calcitonin, Fluoried, Vitamin D, Corticosteroid etc. After measuring the height and weight of each patient the body mass index (BMI, $\mathrm{Kg} / \mathrm{m} 2$ ) was calculated. Physical activity was assessed by the history of walking for exercise hours per day or week, house hold works for house wives, for service holder both service and house hold works. Fieldwork for farming was considered as hard physical activity in rural women. History of smoking was classified as nonsmoker and smoker for more than five years.

\section{Bone densitometry}

Bone mineral density of lumbar spines (L2-L4) in anterior-posterior position and hip were measured using the Dual Energy X-Ray AbsorptiometryDXA (Norland XR36) in two Nuclear Medicine centers attached with Medical Collage Hospitals in Dhaka city from March 2005 to February 2006. The $\mathrm{T}$ score were calculated and results were compared between rural and urban women and also the rate of occurrence of osteoporosis in two groups were determined. The history of physical activity, body mass index (BMI), dietary intake of calcium, smoking habit, number of parity and socio-economic condition was also compared with BMD.

\section{RESULTS}

Out of 376 women, 206 (54\%) women were from rural area or in group I and 172(46\%) women were from urban area and in group II (Table1).

Table 1: Distribution of the study population $(n=$ 376) in percentage.

\begin{tabular}{ccc}
\hline Group & Number of Patients & Percentage (\%) \\
\hline I (Rural) & 204 & 54 \\
II (Urban) & 172 & 46 \\
\hline Total & $\mathbf{3 7 6}$ & $\mathbf{1 0 0}$ \\
\hline
\end{tabular}

The body mass index (BMI; $\mathrm{Kg}$ /square $\mathrm{m}$ ) was calculated from the height, weight of each woman. The mean BMI was higher in urban women than rural women and higher BMI showed a positive association with higher bone mineral density. The mean BMI in rural group was $21.87 \mathrm{Kg} / \mathrm{m} 2$ and in urban was $25.64 \mathrm{Kg} / \mathrm{m} 2$, shown in Table 2 .

Table 2: BMI (body mass index) in the study population $(n=376)$.

\begin{tabular}{ccccc}
\hline Group & $\begin{array}{c}\text { No. of } \\
\text { Patients }\end{array}$ & $\begin{array}{c}\text { Minimum } \\
\text { BMI } \\
\left(\mathrm{kg} / \mathrm{m}^{2}\right)\end{array}$ & $\begin{array}{c}\text { Maximum } \\
\text { BMI } \\
\left(\mathrm{kg} / \mathrm{m}^{2}\right)\end{array}$ & $\begin{array}{c}\text { Mean } \\
\text { BMI } \\
\left(\mathrm{kg} / \mathrm{m}^{2}\right)\end{array}$ \\
\hline I (Rural) & 204 & 13.2 & 24.8 & 21.87 \\
II (Urban) & 172 & 15.6 & 30.1 & 25.64 \\
\hline
\end{tabular}


The mean $\mathrm{T}$ score of lumbar spines in rural group was- $2.31 \pm 1.10$ and in urban group was $-1.78 \pm 1.03$.

The hip of rural group showed mean $\mathrm{T}$ score $3.11 \pm 1.09$ and urban group $-3.02 \pm 1.09$. Our study showed lower mean of bone mineral density in rural women than urban. After statistical analysis it revealed that the difference was statistically not significant, which was observed between the two groups ( $\mathrm{P}<0.01$ and $\mathrm{P}<0.02$ respectively) (Table $3)$.

Table 3: Distribution of $T$-scores in the study population $(n=376)$.

\begin{tabular}{cccccc}
\hline Area & Group & $\begin{array}{c}\text { Minimum } \\
\text { T-Score }\end{array}$ & $\begin{array}{c}\text { Maximum } \\
\text { T-Score }\end{array}$ & $\begin{array}{c}\text { Mean ( } \pm \text { SD) } \\
\text { T-Score }\end{array}$ & $\begin{array}{c}\mathbf{p} \\
\text { value* }\end{array}$ \\
\hline \multirow{3}{*}{$\begin{array}{c}\text { Lumbar } \\
\text { Spines }\end{array}$} & & & & & \\
\cline { 2 - 6 } & Group-I & -4.27 & -0.44 & $-2.31( \pm 1.10)$ & 0.01 \\
& Group-II & -3.91 & -0.61 & $-1.78( \pm 1.03)$ & \\
\multirow{2}{*}{$\begin{array}{c}\text { Femoral } \\
\text { Neck }\end{array}$} & Group-I & -4.69 & -0.54 & $-3.11( \pm 1.09)$ & 0.02 \\
& Group-II & -4.18 & -0.77 & $-3.02( \pm 1.09)$ & \\
\hline
\end{tabular}

$* \mathrm{t}$-test was done to see the significance

In rural group, $39.2 \%$ cases showed osteoporosis in lumbar spines and $76.4 \%$ cases in hip. In comparison the urban group revealed osteoporosis in lumbar spines in $22.7 \%$ cases and in hip $40.9 \%$ cases (Table 4).

Table 4: Distribution of osteoporosis in Lumbar spines and Neck femur in both groups.

\begin{tabular}{llcc}
\hline Group & Area & No of patients & Percentage (\%) of osteoporosis \\
\hline Group-I & Lumbar Spines & 156 & 76.4 \\
& Femoral Neck & 83 & 40.9 \\
\hline Group-II & Lumbar Spines & 67 & 39.2 \\
& Femoral Neck & 39 & 22.7 \\
\hline
\end{tabular}

The women from rural part, $58 \%$ of them had increased number of parity (more than 5 children) and were living with low socioeconomic condition compared to the urban women. The women from both rural and urban areas $99 \%$ were nonsmoker. The life style and physical activity showed no association with BMD.

\section{DISCUSSION}

Over the past decade, osteoporotic fractures have been recognized as one of the most serious problems in public health. For a 50 years old white woman, the risk of fracture of the spine, hip, or forearm is estimated to be $30 \%$ to $40 \%$, which compares with the percentage of breast cancer and cardiovascular disease of $9 \%-12 \%$ and $30 \%-40 \%$, respectively (8). In the United States, 10 million individuals over the age of 50 years about 8 million women and 2 million men are estimated to already have osteoporosis. These numbers are expected to increase to an estimated 14 million individuals with osteoporosis and more than 47 million cases of low bone mass by 2020 . The health care costs due to osteoporosis in the United States were estimated to be between $\$ 13.7$ billion and $\$ 20.3$ billion in 2005 . It is projected that by 2025 , there will be over 3 million fractures, with related expenditures of $\$ 25.3$ billion per year $(9$, 10).

Hip fracture is associated with greater morbidity and mortality, disability and incurs significant economic and social costs (7). Bone mineral density (BMD), a measure of bone strength, is a strong predictor of hip fracture risk (8). Many studies carried out both in European and Western countries and some in Asian region showed higher bone mineral density and lower osteoporotic fracture in rural population compared to urban population $(1,6)$. But some studies also showed statistically no significant difference in mean values of BMD between urban and rural population $(4,11)$. In our study the women living in rural area showed lower bone mineral density but the difference is statistically not significant. Though statistically insignificant, the study revealed a definite trend towards osteoporosis in the rural group compared to the urban .The reasons for urban and rural differences are largely unknown, particularly in developing countries (4, $6)$. Low body mass index is an established risk factor for osteoporosis (12). Felson et al. 2000 and Reid IR et al.1992 in their studied showed that body weight is strongly related to bone mineral 
density, such that higher weight is associated with both higher BMD and reduced fracture risk $(13,14)$. In a study Dr. Meyer compared the mean distal forearm BMD between urban and rural county dwellers in Norwegian population and he found lower BMD in urban population. He showed for an increase of $5 \mathrm{~kg}$ /square $\mathrm{m}$ in body mass index, BMD increased by $0.014 \mathrm{~g}$. square $\mathrm{cm}$ in women. The author gave his opinion for the higher BMD in rural population were physical exercise and higher body mass compared to the urban (1). Our study showed lower body mass index in rural women compared to the urban dwellers and which might be the factor for lower BMD in rural women. The increased number of parity and low socioeconomic condition also showed positive association of lower BMD.

\section{CONCLUSION}

Though statistically insignificant, the study revealed a definite trend towards osteoporosis in the rural group compared to the urban. However larger sample studies are required to further establish the relationship between the two groups.

\section{REFERENCES}

1. H E Meyer, G KR. Berntsen, A J Sogaard, A Langhammer. Higher bone mineral density in rural compared with rural and urban dwellers. American Journal of Epidemiology 2004; 160(11):1039-1046.

2. Hussain Raihan. Obesity as a safety factor in Osteoporosis-DEXA study in post menopausal women. Bangladesh J. Nucl. Med.2005; 8(2): 8487.

3. Lusetto G, Zangari M, Bottega F et al. Different rates of forearm bone loss in healthy women with early or late menopause. Osteoporosis Int. 1995; 5: 54-62.

4. Rafal S. Filip, Jerzy Zagorski. Bone mineral density and osteoporosis in rural and urban women. Epidemiological study of the Lublin region (Eastern Poland). Ann Agric Environ Med 2001; 8:221-226. 4

5. Fogelman I, Blaek GM. Different approaches to bone densitometry. J Nucl Med 2000; 41(12):20152025. 5

6. Ongchaiyakul C, Nguyen TV, Kosulwat V et.al. Contribution of lean tissue mass to the urban-rural difference in bone mineral density. Osteoporosis Int.2005 May 12. 6

7. Centre JR, Nguyen TV, Schneider D, Sambrook PN, Eisman JA. Mortality after all major types of Osteoporotic fracture in men and women: an observational study. Lancet 1999:353(9156): 878882.

8. Cummings SR, Bates D, Black DM: Clinical use of bone densitometry: scientific review. JAMA2002;288(15):1889-1897.

9. National Osteoporosis Foundation. America's bone health: the state of osteoporosis and low

bone mass in our nation. http:// www.osteoporosisnews.org/advocacy/prevalence/in dex.htm. Published 2002. Accessed February 22, 2011.

10. Burge R, Dawson-Hughes B, Solomon DH, Wong JB, King A, Tosteson A. Incidence and economic burden of osteoporosis related fractures in the United States, 2005-2025. J Bone Miner Res. 2007; 22(3).465-475.

11. New Filip RS, Zagórski J. Bone mineral density and osteoporosis in rural and urban women. Epidemiological study of the Lublin region (Eastern Poland). Ann Agric Environ Med. 2001; 8(2):221-6.

12. Espallargues M, Sampietro-Colom L, Estrada MD, et al. Identifying bone-mass-related risk factors for fracture to guide bone densitometry measurements: a systematic review of the literature. Osteoporos Int 2001;12: 811-22.

13. Felson Dt, Zhang Y, Hannan MT, Anderson JJ. Effects of weight and body mass index on bone mineral density in men and women: the Framingham study. J Bone Miner Res. 1993; 8(5):567-573.

14. Reid IR, Ames R, Evans MC, Sharpe $\mathrm{S}$ et al. Determination of total body and regional bone mineral density in normal postmenopausal womena key role for fat mass. J Clin Endocrinol Metab 1992; 75(1):45-51. 